\title{
EVALUATION OF BLOOD TRANSFUSION EFFECTS ON MIXED VENOUS OXYGEN SATURATION AND LACTATE LEVELS IN PATIENTS WITH SIRS/SEPSIS
}

\author{
Bruno Franco Mazza, Flávia Ribeiro Machado, Débora Dutra Mazza, and Valeria
} Hassmann

\begin{abstract}
Mazza BF, Machado FR, Mazza DD, Hassmann V. Evaluation of blood transfusion effects on mixed venous oxygen saturation and lactate levels in patients with SIRS/sepsis. Clinics. 2005;60(4):311-6.
\end{abstract}

PURPOSE: To evaluate the effects of red blood cell transfusion in patients with SIRS/sepsis who presented hemoglobin levels under $9.0 \mathrm{~g} / \mathrm{dL}$ at intensive care unit admission, using two parameters of organ perfusion: mixed venous oxygen saturation and serum lactate levels.

METHODS: All patients admitted to the intensive care unit with SIRS/sepsis, as defined by Consensus Conference in 1992, and hemoglobin levels under $9.0 \mathrm{~g} / \mathrm{dL}$ were included. Hemoglobin levels, mixed venous oxygen saturation, and lactate levels were collected before red blood cell transfusion (pre-T) and up to 1 hour after transfusion (post-T). These variables were analyzed through a paired t test, and results were considered significant if $P \leq .05$.

RESULTS: Twenty-nine patients ( 17 male, 12 female) with ages of $61.9 \pm 15.1$ (mean \pm SD) years (range, 21-85 years) and a mean APACHE II score of $12.5 \pm 3.75$ (7-21) were transfused with a mean of 1.41 packed red cell units. A significant increase in hemoglobin levels was reached by blood transfusion, from $8.14 \pm 0.64 \mathrm{~g} / \mathrm{dL}$ (pre-T) to $9.4 \pm 0.33 \mathrm{~g} / \mathrm{dL}$ (post-T), with $P<.001$. However, this was not accompanied by a significant change in lactate levels, from $1.87 \pm 1.22 \mathrm{mmol} / \mathrm{l}(\mathrm{pre}-\mathrm{T}$ ) to $1.56 \pm 0.28 \mathrm{mmol} / \mathrm{l}$ (post-T), with $P=.28$, or in mixed venous oxygen saturation, from $64.3 \pm 8.52 \%$ (pre-T) to $67.4 \pm$ $6.74 \%$ (post-T), with $P=.13$. The results were similar even in patients with hemoglobin levels under $8.0 \mathrm{~g} / \mathrm{dL}(\mathrm{n}=9$ ).

These results suggest that red blood cell transfusions, in spite of leading to a significant increase in hemoglobin levels, are not associated with an improvement in tissue oxygenation in patients with SIRS/sepsis and hemoglobin levels $<9 \mathrm{~g} / \mathrm{dL}$.

KEYWORDS: Red blood cell transfusion. Mixed venous oxygen saturation. Serum lactate. Tissue oxygenation. Sepsis.

Anemia is a common finding in patients admitted to the ICU. Studies have shown that $77 \%$ of these patients present anemia during their hospital stay, and more than one third of them end up receiving a red blood cell transfusion. Anemia is secondary to multiple factors. In addition to blood loss provoked by evident bleedings, including iatrogenic anemia, which is caused by collection of blood samples for exams, invasive procedures; nutrition failure; hemolysis; occult blood loss; and endocrine, renal or hepatic system alterations can also lead to a decrease in erythropoietin release, which causes a decreases erythropoiesis. ${ }^{1,2}$

Intensive Care Unit, Discipline of Anesthesiology, Pain and Intensive Care, Federal University of São Paulo - São Paulo/SP, Brazil.

Critmed, Santa Casa de Misericórdia - Cruzeiro/SP, Brazil.

E-mail : genauhaus@uol.com.br

Received for publication on March 16, 2005.

Accepted for publication on April 29, 2005.
On the other hand, it is known that the action of inflammatory cytokines, such as tumoral necrosis factor (TNF-a), interleukin-1 (IL-1), and interleukin-6 (IL-6), correlates to a decrease of erythropoietin production. Interferon gamma and IL-1 also seem to act directly, inhibiting the growth of pro-erythrogenic cells, contributing to the development of anemia in these patients. ${ }^{3}$

Thus, red blood cell transfusion has been often used on patients admitted to ICU. Two studies assessed the incidence of anemia and the use of blood transfusion in Europe and the United States. The European study has shown a transfusion rate of $37 \%$ during the ICU stay, whereas the American study shows that about $44 \%$ of ICU patients underwent transfusion. The mean pretransfusion hemoglobin $(\mathrm{Hb})$ values were $8.4 \mathrm{~g} / \mathrm{dL}$ and $8.6 \mathrm{~g} / \mathrm{dL}$, respectively. However, both studies show that transfusion was associated with a worse prognosis. ${ }^{4,5}$ Moreover, blood transfusion has exhibited sev- 
eral adverse effects that must be assessed when deciding whether to use it. Complications are described in about $20 \%$ of transfusions ${ }^{6}$ and can be classified as infectious and noninfectious. Among the infectious complications are the transmission of agents, such as hepatitis B and C virus, HIV, cytomegalovirus, and human T cell lymphotropic virus HTLV, as well as the risk of Chagas and syphilis transmission, among others. The noninfectious complications are related to concomitant transfusions of leucocytes, such as fever, alloimmunization, refractoriness to platelet transfusion, acute lung injury, and immunossupression. ${ }^{78}$ A retrospective study has shown that blood transfusion was related to a greater rate of hospital infection. ${ }^{10}$ Other undesirable effects caused by the use of blood-derived substances are lung edema due to hypervolemia, hypothermia, coagulopathies, and toxicity due to citrate. ${ }^{9}$

Thus, blood transfusion has poses a difficult problem in ICUs, and there are still many controversial aspects related to its benefits, as well as to the risks of keeping lower levels of $\mathrm{Hb}$ in patients. In a recent study, Hébert et al. ${ }^{11}$ did not find benefits related to keeping $\mathrm{Hb}$ between 10 and $12 \mathrm{~g} / \mathrm{dL}$, when compared to a group with $\mathrm{Hb}$ between 7 and $9 \mathrm{~g} / \mathrm{dL}$, in ICU patients. However, when the subgroup of patients with previous heart disease was analyzed, the restrictive strategy was associated with an increased death risk in these patients.

Patients with SIRS/sepsis usually present abnormalities in oxygen consumption. The treatment of these patients aims at optimizing tissue oxygen extraction through the maintenance of an adequate oxygen delivery, reducing the progression of cell dysfunction, and hence, avoiding a multiple organ dysfunction syndrome. ${ }^{12}$ Mixed venous oxygen saturation $\left(\mathrm{SvO}_{2}\right)$ and serum lactate are valuable markers in the assessment of cell metabolism as indirect measures of oxygen tissue delivery, and are therefore important variables in monitoring patients admitted to ICU. Monitoring of $\mathrm{SvO}_{2}$ evaluates the balance between the delivery and consumption of oxygen, which is decreased when there is a delivery decrease and/or a consumption increase. The presence and persistence of high levels of lactate are related to increases in morbidity and mortality. ${ }^{13,14}$

The maintenance of adequate $\mathrm{Hb}$ levels was suggested as a way of increasing the tissue oxygen delivery when SIRS/sepsis occurs, leading to an improvement in tissue hypoperfusion. ${ }^{15}$ In a recent study, the early optimization of $\mathrm{SvO}_{2}$ has shown itself efficient concerning mortality reduction in patients with severe sepsis. Part of that strategy was based on keeping the hematocrit above $30 \% .{ }^{20}$ But transfusion can also provoke a decrease in tissue oxygen delivery because of the reduction in tissue flow in the microcirculation, deriving from increased blood viscosity.
This effect would become more severe when stored blood is used, since the red cell morphology is compromised and the function of 2,3-diphosphoglycerate (2,3 DPG) altered, provoking a decrease in oxygen delivery. ${ }^{17,18}$

There are no definite data concerning the ideal value of $\mathrm{Hb}$ for patients admitted to the ICU. ${ }^{16}$ This study aims at determining the effect of blood transfusion on tissue oxygen delivery as assessed by $\mathrm{SvO}_{2}$ and serum lactate in patients with SIRS/sepsis with $\mathrm{Hb}$ levels $<9 \mathrm{~g} / \mathrm{dL}$.

\section{METHODS}

The study was performed in a general ICU from February 2001 to October 2002. The protocol was approved by the Ethics Committee of the institution, and all the patients or their legal representatives agreed with their participation. Patients with minimum age of 15 years were included when they met the following inclusion criteria:

- Diagnosis of SIRS/sepsis, determined by the presence of, at least, 2 of the criteria of the Consensus Conference of $1992^{19}$ :

- Core temperature $>38^{\circ} \mathrm{C}$ or $<36^{\circ} \mathrm{C}$;

- Heart rate $>90$ beats per minute;

- Respiratory rate $>20$ inhalations per minute or $\mathrm{PaCO}_{2}<32 \mathrm{~mm} \mathrm{Hg}$;

- WBC count higher than $12,000 / \mathrm{mm}^{3}$ or lower than $4,000 / \mathrm{mm}^{3}$ or with more than $10 \%$ immature forms (bands);

- $\mathrm{Hb}<9.0 \mathrm{~g} / \mathrm{dL}$;

- Invasive hemodynamic monitoring with Swan-Ganz catheter with occluded pulmonary artery pressure $>12$ $\mathrm{mm} \mathrm{Hg}$, as a marker of normovolemic status.

The exclusion criteria were pregnancy, brain death, or expected death in less than 24 hours.

Blood was collected from all patients in order to analyze $\mathrm{Hb}$ concentration, $\mathrm{SvO}_{2}$ through the distal lumen of the Swan-Ganz catheter, and arterial lactate immediately before the start of transfusion (pre-T) and 1 hour after the end of the red blood cell transfusion (post-T). The number of red blood cells to be transfused was determined by the initial $\mathrm{Hb}$ rate: 1 packed red blood cell unit in patients with $\mathrm{Hb}$ level between 8 and $9.0 \mathrm{~g} / \mathrm{dL}, 2$ packed red blood cell units when they presented $\mathrm{Hb}$ level between 7 and $8 \mathrm{~g} / \mathrm{dL}$, and 3 packed red blood cell units when the $\mathrm{Hb}$ level was lower than $7 \mathrm{~g} / \mathrm{dL}$.

Analyzing the results, we considered both the total group of patients as well as the subgroup with $\mathrm{Hb}$ between 8 and $9 \mathrm{~g} / \mathrm{dL}$ (Group 8-9) and the subgroup with Hb lower than $8 \mathrm{~g} / \mathrm{dL}$ (Group $<8$ ). The data were expressed as mean \pm standard deviation and analyzed by the ANOVA test. The results were considered significant when $P \leq .05$. As our 
sample is small, a power analysis was performed. A difference of $5 \%$ in $\mathrm{SvO}_{2}$ and $0.5 \mathrm{mmol} / \mathrm{k}$ in lactate levels was considered clinically significant. Based on these values as the expected difference and on our own data, the power of each analysis (global, Group 8-9, and Group <8) was determined.

\section{RESULTS}

Twenty-nine patients with ages of $62 \pm 15$ years were included (17 men and 12 women). The mean APACHE II was $12.5 \pm 3.75$. (Table 1 ). There were 20 patients in Group $8-9$ and 9 in Group < 8. No immediate complications were noticed after the blood transfusion.

Blood transfusion led to a significant increase of $\mathrm{Hb}$ levels. The pre-T value was $8.14 \pm 0.64 \mathrm{~g} / \mathrm{dL}$, increasing to $9.4 \pm 0.33 \mathrm{~g} / \mathrm{dL}(\mathrm{P}<.001)$ post-T. The patients in Group 89 presented $\mathrm{Hb}$ levels of $8.5 \pm 0.27 \mathrm{~g} / \mathrm{dL}$ (pre-T) and $9.47 \pm$ 0.36 (post-T). Patients in Group $<8$ presented $7.34 \pm 0.48$ $\mathrm{g} / \mathrm{dL}$ (pre-T) and $9.23 \pm 0.20$ (post T) (both with $P<.001)$ (Tables 2, 3, and 4).

The $\mathrm{SvO}_{2}$ and the serum lactate showed only mild alteration in post- $T$ values when compared to pre- $T$ (this ap- plies to the total group and the subgroup analysis), without any significant statistical difference. The results of the $\mathrm{SvO}_{2}$ varied from $64.3 \pm 8.52$ (pre-T) to $67.4 \pm 6.74$ (postT), with $P=.13$. Similar results were observed when the subgroups were considered. The $\mathrm{SvO}_{2}$ results in Group 8-9 were $65.8 \pm 8.88$ (pre-T) and $69.7 \pm 6.15$ (post-T), with $P=.11$; and in Group $<8 \mathrm{SvO}_{2}$ results were $62.4 \pm 5.22$ (pre-T) and $62.4 \pm 5.32$ (post-T), with $P>.99$ (Table 2, 3, and 4).

As for the serum lactate, results were similar, without any significant alterations in the patients who received blood transfusion. The lactate values for all patients were $1.87 \pm$ $1.22 \mathrm{mmol} / \mathrm{k}$ (pre-T) and $1.56 \pm 0.93 \mathrm{mmol} / \mathrm{k}$ (post-T), with $P=.28$. The subgroups did not present significant alterations either. In Group 8-9 the serum lactate values were 1.79 $\pm 1.25 \mathrm{mmol} / \mathrm{k}$ (pre-T) and $1.39 \pm 0.96 \mathrm{mmol} / \mathrm{k}$ (post-T), with $P=.26$. In Group $<8$, the lactate values were $2.04 \pm$ $1.2 \mathrm{mmol} / \mathrm{k}$ (pre-T), and $1.92 \pm 0.8 \mathrm{mmol} / \mathrm{k}$ (post-T), with $P$ $=.806$ (Table 2, 3, and 4).

\section{DISCUSSION}

In this study we tried to assess the response to transfusion through $\mathrm{SvO} 2$ and serum lactate. Despite the efficacy

Table 1 - General features of the patients

\begin{tabular}{|c|c|c|c|c|c|c|c|}
\hline Patient & Age & Sex & Diagnosis & $\begin{array}{l}\text { Apache } \\
\text { il score }\end{array}$ & $\begin{array}{c}\text { Initial } \\
\mathrm{HB}(\mathrm{g} / \mathrm{dL})\end{array}$ & $\begin{array}{c}\text { Initial } \\
\mathrm{SVO}_{2}(\%)\end{array}$ & $\begin{array}{l}\text { Initial Lactate } \\
(\mathrm{mmol} / \mathrm{L})\end{array}$ \\
\hline 1 & 56 & male & Pneumonia & 13 & 8.5 & 62 & 1.20 \\
\hline 2 & 66 & male & Mesenteric infarction (PO) & 19 & 8.3 & 54 & 6.30 \\
\hline 3 & 71 & male & Urinary infection & 16 & 8.8 & 77 & 0.88 \\
\hline 4 & 62 & male & Pneumonia & 11 & 7.6 & 52 & 0.59 \\
\hline 5 & 73 & male & Pancreatitis & 15 & 8.0 & 56 & 2.81 \\
\hline 6 & 42 & female & Polytrauma & 8 & 8.5 & 60 & 2.85 \\
\hline 7 & 71 & male & Colectomy (PO) & 11 & 8.9 & 62 & 2.50 \\
\hline 8 & 42 & male & Polytrauma & 8 & 8.4 & 69 & 1.14 \\
\hline 9 & 71 & female & Pneumonia & 13 & 7.4 & 73 & 1.13 \\
\hline 10 & 45 & female & Pancreatitis & 18 & 8.6 & 76 & 2.00 \\
\hline 11 & 81 & male & Urinary infection & 15 & 7.4 & 61 & 2.54 \\
\hline 12 & 64 & female & Aortic aneurysm (PO) & 10 & 7.9 & 58 & 2.24 \\
\hline 13 & 71 & male & Aortic iliac graft (PO) & 10 & 8.3 & 78 & 0.85 \\
\hline 14 & 56 & female & Total hip replacement (PO) & 8 & 8.8 & 74 & 1.43 \\
\hline 15 & 61 & female & Pneumonia & 11 & 8.7 & 70 & 0.80 \\
\hline 16 & 70 & female & Gastrectomy (PO) & 11 & 8.6 & 51 & 1.57 \\
\hline 17 & 52 & male & Polytrauma & 14 & 8.9 & 60 & 0.90 \\
\hline 18 & 53 & male & Pancreatitis & 17 & 8.5 & 64 & 1.57 \\
\hline 19 & 78 & male & Colectomy (PO) & 12 & 6.9 & 62 & 4.48 \\
\hline 20 & 80 & male & Pneumonia & 14 & 7.7 & 63 & 1.64 \\
\hline 21 & 21 & female & Appendicitis (PO) & 8 & 7.4 & 58 & 2.73 \\
\hline 22 & 53 & male & Total hip replacement (PO) & 7 & 8.2 & 50 & 1.63 \\
\hline 23 & 72 & male & Aortic iliac graft (PO) & 10 & 8.2 & 76 & 1.65 \\
\hline 24 & 39 & female & Polytrauma & 8 & 6.3 & 67 & 2.31 \\
\hline 25 & 72 & female & Colectomy (PO) & 10 & 8.3 & 53 & 2.46 \\
\hline 26 & 55 & male & Pancreatitis & 13 & 7.5 & 64 & 0.74 \\
\hline 27 & 52 & male & Intestinal obstruction (PO) & 14 & 8.1 & 71 & 1.21 \\
\hline 28 & 85 & female & Pneumonia & 18 & 8.5 & 74 & 1.05 \\
\hline 29 & 82 & female & Urinary tract infection & 21 & 8.8 & 72 & 0.97 \\
\hline
\end{tabular}

$\mathrm{PO}$ - postoperative, $\mathrm{HB}$ - hemoglobin, $\mathrm{SVO}_{2}$ - mixed venous oxygen saturation 
Table 2 - Hemoglobin, mixed venous oxygen saturation and serum lactate pre- and post-transfusion global analysis

\begin{tabular}{lccc}
\hline & $\begin{array}{c}\text { Pre- } \\
\text { Transfusion }\end{array}$ & $\begin{array}{c}\text { Post- } \\
\text { Transfusion }\end{array}$ & $P^{\#}$ \\
\hline Hemoglobin $(\mathrm{g} / \mathrm{dL})$ & $8.14 \pm 0.64$ & $9.4 \pm 0.33$ & $<.001$ \\
$\mathrm{SvO}_{2}(\%)$ & $64.3 \pm 8.52$ & $67.4 \pm 6.74$ & .13 \\
Serum lactate $(\mathrm{mmol} / \mathrm{l})$ & $1.87 \pm 1.22$ & $1.56 \pm 0.93$ & .28 \\
\hline
\end{tabular}

\# ANOVA. Power analysis: $\mathrm{SvO}_{2}=.99$, serum lactate $>.99$; All results are expressed in mean \pm standard deviation; $\mathrm{SvO}_{2}$. Mixed venous oxygen saturation

Table 3 - Hemoglobin, mixed venous oxygen saturation and serum lactate pre- and post-transfusion in the subgroup with hemoglobin between $8-9 \mathrm{~g} / \mathrm{dL}$

\begin{tabular}{lccc}
\hline & $\begin{array}{c}\text { Pre- } \\
\text { Transfusion }\end{array}$ & $\begin{array}{c}\text { Post- } \\
\text { Transfusion }\end{array}$ & $P^{\#}$ \\
\hline Hemoglobin (g/dL) & $8.5 \pm 0.027 *$ & $9.4 \pm 0.36 *$ & $<.001$ \\
SvO $_{2}(\%)$ & $65.8 \pm 8.88 * *$ & $69.7 \pm 6.10 * *$ & .11 \\
Serum lactate (mmol/1) & $1.79 \pm 1.25 * * *$ & $1.39 \pm 0.26 * * *$ & .26 \\
\hline
\end{tabular}

\# ANOVA. Power analysis: $\mathrm{SvO}_{2}=.93$, serum lactate $>.99$; All results are expressed in mean \pm standard deviation; $\mathrm{SvO}_{2}$. Mixed venous oxygen saturation

Table 4 - Hemoglobin, mixed venous oxygen saturation and serum lactate pre and post-transfusion in the subgroup with hemoglobin $<8 \mathrm{~g} / \mathrm{dL}$

\begin{tabular}{lccc}
\hline & $\begin{array}{c}\text { Pre- } \\
\text { Transfusion }\end{array}$ & $\begin{array}{c}\text { Post- } \\
\text { Transfusion }\end{array}$ & $P^{\#}$ \\
\hline Hemoglobin $(\mathrm{g} / \mathrm{dL})_{\mathrm{SvO}_{2}(\%)}^{7.34 \pm 0.48 *}$ & $9.23 \pm 0.20 *$ & $<0.0001$ \\
Serum lactate $(\mathrm{mmol} / \mathrm{l})$ & $2.02 .4 \pm 5.22 * *$ & $62.4 \pm 5.32 * *$ & 1 \\
\hline
\end{tabular}

\# ANOVA. Power analysis: $\mathrm{SvO}_{2}=0,94$, serum lactate $=0.47$; All results are expressed in mean \pm standard deviation; $\mathrm{SvO}_{2}$. Mixed venous oxygen saturation

of transfusions i.e., the significant increase of $\mathrm{Hb}$ levels, there was no improvement regarding the indirect markers of tissue perfusion. It may be argued that such small differences in hemoglobin levels would not be enough to change tissue perfusion. However, in clinical practice, the value of $9.0 \mathrm{~g} / \mathrm{dL}$ is considered a cutoff level, below which the perfusion would be compromised. Actually, this level is currently used as a transfusion threshold in many intensive care units. Based on this, it was considered as a target in the present study.

The $\mathrm{SvO}_{2}$ and the serum lactate are considered the best markers of tissue oxygen delivery, and they can be used as a guide in clinical practice. The normal value for the $\mathrm{SvO}_{2}$, and the therapeutic goal in septic shock, is $>70 \%$. Rivers et al. used central venous oxygen saturation $\left(\mathrm{SvcO}_{2}\right)>70 \%$ as a target in the initial period of resuscitation in patients with septic shock, and they were able to demonstrate a significant decrease in hospital mortality. ${ }^{20}$

In our protocol we used mixed venous oxygen saturation, a more reliable marker than $\mathrm{SvcO} 2$ in terms of global tissue perfusion, and the observed values were very low. The correct clinical procedure is to increase oxygen delivery. The question is whether this should be done through a red blood cell transfusion or through volume replacement, either with colloids or crystalloids, or even with dobutamine.

Rivers et al. ${ }^{20}$ showed that patients who did not have their $\mathrm{SvcO}_{2}$ normalized after volume replacement and use of vasoconstrictors received blood transfusion until the hematocrit reached 30\%. Only after that was dobutamine given. Through this approach, they claim a significant decrease in mortality. However, they do not mention either the percentage of patients that effectively presented an improvement in $\mathrm{SvcO}_{2}$ after transfusion or the extent of that improvement, and did not consider the alterations in serum lactate levels. Our study shows that transfusion was not efficient in optimizing $\mathrm{SvO}_{2}$, nor in causing lactate to return to normal levels, although the majority of patients did reach a hematocrit of $30 \%$, That seems to suggest that transfusions could work through volemic improvement rather than through oxygen-carriage optimization. It is possible that volemic improvement was responsible for the $\mathrm{SvO}_{2}$ increase with a consequent decrease in mortality. It is known that the use of crystalloids or colloids increases the tissue oxygen delivery due to an increase in preload and better cardiac output. Unfortunately, we did not record post-T pulmonary capillary pressure values, which would show whether the volemic status was improved by transfusion in our patients. Nonetheless, increasing effectively the $\mathrm{Hb}$ levels did not improve the oxygen tissue delivery in our study.

On the other hand, Hébert et al. ${ }^{11}$ reported that a restrictive strategy in terms of blood transfusions was adequate, with a mortality rate lower than that observed in the group that received more transfusions. However, this difference was not statistically significant. Therefore, that study suggests that $\mathrm{Hb}$ levels over $7.0 \mathrm{~g} / \mathrm{dL}$ are sufficient to guarantee adequate oxygen delivery. It is notable that those authors assessed a general population of critically ill patients and not specifically a septic population of patients. Due to the peculiarities of septic patients, such as, cytopathic hypoxemia ${ }^{21}$ and microcirculatory thrombosis, which impairs blood flow, ${ }^{22}$ it is possible that these patients have a different response to low levels of $\mathrm{Hb}$. Had a septic population been studied, results might have been worse in terms of mortality reduction.

Moreover, because of the deficient circulation, the problems derived from the stored-blood transfusion are also potentially higher, as these red cells exhibit decreased rheologic 
properties and an alteration in 2,3 DPG. ${ }^{23}$ This could lead to a decrease in the oxygen-delivery capacity of these cells. Thus, the transfusion would not only fail to have any effect in the optimization of the tissue oxygen delivery, but might also contribute to the altered values of the venous oxygen saturation and serum lactate. The mean time of blood storage in the hospital where the study was performed is 15 days.

One possible explanation for the absence of alterations in tissue oxygenation parameters would be that the hemoglobin levels were not low enough to contribute to a decrease in tissue oxygen delivery, because the mean value of $\mathrm{Hb}$ was 8.14 $\pm 0.64 \mathrm{~g} / \mathrm{dL}$. It is possible that the basic problem of the patients was not the hemoglobin, but rather the volemic status or even the myocardial depression related to sepsis. Even so, we can still suppose those $\mathrm{Hb}$ levels are sufficient to guarantee an adequate oxygen transport in this population.

One limitation of our study is the small number of patients. It is possible that due to the small power, a type 2 error may have occurred. Nonetheless, statistical analysis showed high power to detect clinically significant differences in $\mathrm{SvO}_{2}$ and serum lactate, with exception of the former in the subgroup of patients with $\mathrm{HB}<8.0 \mathrm{~g} / \mathrm{dL}$. In this small subgroup, as the number of individuals is too low, the results could be questionable, and a type 2 error is possible. However, this is the group whose response to transfusion was supposed to be more pronounced, and values for $\mathrm{SvO}_{2}$ and lactate were nearly unchanged. This suggests that a sig- nificant difference does not exist, and even with a larger sample we would not be able to demonstrate it.

Another limitation is the age variability in our group of patients. It is known that transfusion effects can be very different in young patients comparing to older ones. In the CRIT study, ${ }^{5}$ the detrimental effects of transfusion were significant only in the subgroup of patients under 55 years. This might be related to a high incidence of ischemic cardiovascular disease in the older group. Therefore, it is possible that the benefits of transfusion in our group were obscured due to this great variability. However, although the mean age was similar in both studies $(62 \pm 15$ years and $60 \pm 18$ years, respectively) only $17 \%$ of our patients were younger than 50 years compared to $30 \%$ in the CRIT study. This finding suggests that if there is a benefit in transfusion, it would have been easier to prove it in our population than it would in an older one. Unfortunately, a subgroup analysis was precluded by the small number of patients in both groups.

In conclusion, the significant increase of $\mathrm{Hb}$ levels after blood transfusion that occurred in our studied groups, was not accompanied by alterations of $\mathrm{SvO}_{2}$ and lactate levels. This result suggests that a more restrictive strategy related to blood transfusion should be used on patients admitted to the ICU.

The risks and benefits of blood transfusions must always be taken into account, even when the patients present a tissue oxygen delivery failure.

\section{RESUMO}

Mazza BF, Machado FR, Mazza DD, Hassmann V. Avaliação dos efeitos da transfusão de sanguínea na saturação venosa mista e nos níveis de lactato em pacientes com SIRS/sepse. Clinics. 2005;60(4):311-6.

OBJETIVOS: Avaliar o efeito da transfusão de hemáceas em pacientes com SIRS/sepse que apresentaram níveis de hemoglobina abaixo de 9,0g/dL durante internação em unidade de terapia intensiva, usando dois parâmetros de perfusão orgânica, a saturação venosa mista de oxigênio e os níveis de lactato sérico.

MÉTODOS: Todos os pacientes admitidos na Unidade de Terapia Intensiva com SIRS/sepse, como definido pela Conferência de Consenso de 1992, e níveis de hemoglobina abaixo de 9,0g/dL foram incluídos. Os níveis de hemoglobina, saturação venosa mista de oxigênio e lactato sérico foram coletados antes (pré-T) e após uma hora da transfusão de hemáceas (pós-T). Essas variáveis foram analisadas através do teste $\mathrm{T}$ de Student pareado e os resultados considerados significativos se $\mathrm{p}<0,05$.

RESULTADOS: Vinte e nove pacientes (17 homens e 12 mulheres) com idade média de 61,9 $\pm 15,1$ anos (21-85anos) e índice APACHE II de 12.5 \pm 3.75 (7-21) foram transfundidos com uma média de 1,41 unidades de hemáceas. Um aumento significativo dos níveis de hemoglobina foi atingido com a

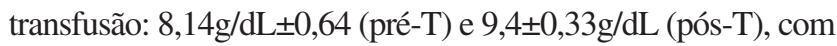
$\mathrm{p}<0,0001$. Entretanto, isso não foi acompanhado por mudança significativa dos níveis de lactato: $1,87 \pm 1,22 \mathrm{mmol} / \mathrm{l}$ (pre-T) e $1,56 \pm 0,28 \mathrm{mmol} / \mathrm{k}$ (pós-T), com $\mathrm{p}=0,28$, ou da saturação venosa mista de oxigênio: $64,3 \pm 8,52 \%$ (pre-T) e $67,4 \pm 6,74 \%$ (pós$\mathrm{T})$, com $\mathrm{p}=0,13$. Os resultados foram semelhantes mesmo nos pacientes com hemoglobina abaixo de $8,0 \mathrm{~g} / \mathrm{dL}$. Todos os resultados estão expressos em média \pm desvio padrão

Esses resultados sugerem que transfusões de hemácias, apesar de levarem a aumento significativo dos níveis de hemoglobina, não estão associadas à melhora da oxigenação tecidual em pacientes com SIRS/sepse e hemoglobina abaixo de 9,0g/dL.

UNITERMOS: Transfusão de hemácias. Saturação venosa mista de oxigênio lactato sérico. Oxigenação tecidual. Sepse. 
1. Vincent JL, Sakr Y, Creuteur J. Anemia in the intensive care unit. Can J Anesth. 2003;50(6):S53-9.

2. Nguyen BV, Bita DP, Mélot C, Vincent JL. Time course of hemoglobin concentrations in nonbleeding intensive care unit patients. Crit Care Med. 2003;31(2):406-10.

3. Faquin WC, Scheneider TJ, Goldberg MA. Effect of inflammatory cytokines on hypoxia induced erythropoietin production. Blood. 1992;79(8):1887-94.

4. Vincent JL, Baron JF, Rheinhart K, Gattinoni L, Thijs L, Webb A, et al. Anemia and blood transfusion in critically ill patients. JAMA. 2002;288(12):1499-07.

5. Corwin HL, Gettinger A, Pearl RG, Fink MP, Levy MM, Abraham E, et al. The CRIT Study: Anemia and blood transfusion in the critically ill current clinical practice in the United States. Crit Care Med. 2004;32(1):39-52.

6. Walker RH. Transfusions risks. Am J Clin Pathol. 1987;88(3):37478 .

7. Perrota PL, Snyder PL. Non-infectious complications of transfusion therapy. Blood Rev. 2001;15(2):69-83.

8. Mercuriali F, Inghilleri G. Transfusion Risks and limitations. Minerva Anestesiol. 1999;65(5):286-92.

9. Goodnough LT. Risks of blood transfusion. Crit Care Med. 2003;31(12):S678-86.

10. Taylor RW, Manganaro L, O'brien J, Trottier SJ, Parkar N, Veremakis C, et al. Impact of allogenic packed red blood cell transfusion on nosocomial infection rates in the critically ill patient. Crit Care Med. 2002;30(10):2249-54.

11. Hébert PC, Wells G, Blajchman MA, Marshall J, Martin C, Pagliarello $\mathrm{G}$, et al. A multicenter randomized controlled clinical trial of transfusion requirements in critical care. N Engl J Med. 1999;340(6):409-17.

12. Task Force of the American College of Critical Care Medicine: Practice parameters for hemodynamic support of sepsis in adult patients in sepsis. Crit Care Med. 1999;27(3):639-60.
13. Rivers EP, Ander DS, Powell D. Central venous oxygen saturation monitoring in the critically ill patient. Curr Opin Crit Care. 2001;7(3):204-11.

14. Bakker J. Blood lactate levels. Curr Opin Crit Care. 1999;5(3):23439.

15. Weg JG. Oxygen transport in adult respiratory distress syndrome and other acute circulatory problems: relationship of oxygen delivery and oxygen consumption. Crit Care Med. 1991;19(5):65057

16. Hébert PC, Tinmouth A, Corwin H. Anemia and red cell transfusion in critically ill patients. Crit Care Med. 2003;31(12):S672-77.

17. Marik PE, Sibbald WJ. Effect of stored-blood transfusion on oxygen delivery on patients with sepsis. JAMA. 1993;269(23):3024-29.

18. Hammed SM, Aird WC, Cohn M. Oxygen delivery. Crit Care Med. 2003;31(12):S658-67.

19. Society of Critical Care Medicine Consensus Conference Committee. American College of Chest Physicians / Society of Critical Care Medicine Consensus Conference: Definitions for sepsis and organ failure and guidelines for the use of innovative therapies in sepsis. Crit Care Med. 1992;20(6):864-74.

20. Rivers EP, Nguyen B, Havstad S, Ressler J, Muzzin A, Knoblich B, et al. Early goal-directed therapy in the treatment of severe sepsis and septic shock. N Engl J Med. 2001;345(19):1368-77.

21. Fink MP. Cytopathic hypoxia. Mitochondrial dysfunction as mechanisms contributing to organ dysfunction in sepsis. Crit Care Clin. 2001;17(1):219-37.

22. Tem Cate H. Pathophysiology of disseminated intravascular coagulation in sepsis. Crit Care Med. 2000;28(9):S9-11.

23. Schate M, Fink MP. Red blood physiology in critical illness. Crit Care Med. 2003;31(12):S651-57. 